\title{
Agronomic Application of Olive Mill Wastewater with Rock Phosphate Influence Soil Phosphorus Availability, Arbuscular Mycorrhizal Fungal Colonisation and Olive Tree Performance under Long-Term Field Conditions
}

\section{Beligh Mechri ${ }^{*}$, Meriem Tekaya ${ }^{1}$, Hechmi Cheheb², Mohamed Hammami ${ }^{1}$ and Faouzi Attia ${ }^{3,4}$}

${ }^{1}$ Laboratory of Biochemistry, USCR Mass Spectrometry, LR-NAFS/LR12ES05 LR12ES05 Nutrition Functional Foods and Vascular Health, Faculty of Medicine, University of Monastir, 5019 Monastir, Tunisia

${ }^{2}$ The Olive Tree Institute, Unit Specializing in Sousse, Rue Ibn Khaldoun, B.P. 14, 4061 Sousse, Tunisia

${ }^{3}$ Equipe Agricultural Research, Agronutrition, Carbon, France

${ }^{4}$ LabCom C2R-BIONUT, Toulouse, France

\begin{abstract}
The use of organic acids and phenolic compounds that are present in olive mill wastewater (OMW) represents a new perspective in rock phosphate (RP) research and a possible solution for the recycling of the OMW. To test the hypothesis that OMW applied in combination with Gafsa RP to olive tree plants can affect P mobilisation from RP to olive trees, a field experiment was conducted to evaluate the potential use of OMW with RP as soil amendment on olive tree alkaline soils. Treatment included three levels of OMW and RP application: M0 (non-amended control), M1PN (30 $\mathrm{m}^{3} \mathrm{ha}^{-1}$ of $\mathrm{OMW}+150 \mathrm{~kg} \mathrm{ha}^{-1}$ of RP) and M2PN (60 m $\mathrm{ha}^{-1}$ of OMW+150 kg ha-1 of RP). Five years after the start of the experiment, the available phosphorus decreased significantly. Amended olive trees had lower rate of photosynthates compared to the control, mostly due to decreased sink demand for carbon by the root. The biomass of arbuscular mycorrhizal (AM) fungi and the development of colonisation in the olive tree roots decreased dramatically by the application of OMW and RP. Phenols accumulation in leaves was significantly higher in the OMW and RP amended soils, whereas total chlorophyll, chlorophyll $\mathrm{a}$, and chlorophyll $\mathrm{b}$ in olive trees leaves decreased significantly after agronomic application of OMW and RP. Taken with data from experiments in field conditions, our results suggest that the use of OMW in combination with $\mathrm{RP}$, in order to mobilise P from RP to olive trees, are expected to have a major negative impact on plant performance.
\end{abstract}

Keywords: Olive tree; Arbuscular mycorrhizal fungi; Olive mill wastewater; Rock phosphate; Polyphenol; Carbohydrate

\section{Introduction}

The olive tree (Olea europaea L.) is the most important evergreen tree in Tunisia with 60 million olive trees covering 1.6 million hectares of land, where it is grown traditionally in rain-fed conditions [1]. In recent years, there has been a growing interest in olive oil, due to its antioxidant and health-improving properties that has led to an augmentation in olive production [2,3]. The production of olive oil leads to the co-production of large amounts of olive mill wastewaters (OMW). The annual olive oil production in the Mediterranean basin exceeds two million tones and the respective OMW co-produced may exceed 10 million tones. Tunisia, like other arid countries, has to face the increase of the scarcity of water [4,5]. Moreover, water of good quality is used to irrigate crops more sensitive to water shortage [6,7]. In these conditions, the reuse of OMW may lead to higher and more consistent levels of olive production, thus minimizing the exploitation of fresh water resources.

Soluble fertilizer phosphates are usually too expensive for agriculture in developing countries. Rock phosphates (RP), although relatively insoluble, are abundantly found and easily mined. RP does not provide $\mathrm{P}$ available to plants where the $\mathrm{pH}$ of the soil is greater than 5.5-6 and even under optimal conditions, plant yields are lower than those obtained with soluble phosphate [8]. It is well established that RP application is not economically feasible, particularly at soil conditions characterized by a high $\mathrm{P}$ sorption capacity, low cation exchange capacity, high $\mathrm{pH}$, low rainfall, low organic matter content and low microbial activity [9]. The OMW is a foul smelling acidic wastewater composed of water (83-92\%), organic matter (4-16\%) and minerals (1-2\%) [10]. The combination of RP and OMW presents an attractive, ecologically sound alternative to the intensive use of manufactured $\mathrm{P}$ fertilizers for subsistence farmers in the developing world. This would enable the development of agricultural practices to optimize plant growth and production in calcareous soils with low $\mathrm{P}$.

Olive plants are known to form arbuscular mycorrhizal (AM) fungi $[11,12]$. They play an essential role in enhancing plant growth in semiarid agro-ecosystem [13]. Their effects were well-documented on the enhancement of the phosphorus uptake [14], and on other macroand micro-elements [15]. Mycorrhiza also has a significant role in plants protection against pathogens, increasing the resistance of plants to drought stress, and improving soil texture [16].

Plant mineral nutrition depends mainly on the phosphorus content of soil, which can be assimilated only as soluble phosphate. Hence the use of RP as a fertilizer for P-deficient soils has received significant interest in recent years since they are natural, inexpensive and available fertilizers. However their solubilization rarely occurs in non acidic

*Corresponding author: Beligh Mechri, Laboratory of Biochemistry, USCR Mass Spectrometry, LR-NAFS/LR12ES05 LR12ES05 Nutrition Functional Foods and vascular health, Faculty of Medicine, University of Monastir, 5019 Monastir, Tunisia Tel: +216 73462 200; Fax: + 21673460 737; E-mail: beligh.mechri77@yahoo.fr

Received May 15, 2015; Accepted June 04, 2015; Published June 06, 2015

Citation: Mechri B, Tekaya M, Cheheb H, Hammami M, Attia F (2015) Agronomic Application of Olive Mill Wastewater with Rock Phosphate Influence Soil Phosphorus Availability, Arbuscular Mycorrhizal Fungal Colonisation and Olive Tree Performance under Long-Term Field Conditions. J Environ Anal Toxicol 5: 300. doi:10.4172/2161-0525.1000300

Copyright: $\odot 2015$ Mechri B, et al. This is an open-access article distributed under the terms of the Creative Commons Attribution License, which permits unrestricted use, distribution, and reproduction in any medium, provided the original author and source are credited. 
Citation: Mechri B, Tekaya M, Cheheb H, Hammami M, Attia F (2015) Agronomic Application of Olive Mill Wastewater with Rock Phosphate Influence Soil Phosphorus Availability, Arbuscular Mycorrhizal Fungal Colonisation and Olive Tree Performance under Long-Term Field Conditions. J Environ Anal Toxicol 5: 300. doi:10.4172/2161-0525.1000300

Page 2 of 7

soils [17]. Physical and chemical weathering of mineral phosphates is mainly realised along plant roots in the rhizosphere. This part of soil supports large microbial communities that facilitate weathering of minerals by producing organic acids, phenolic compounds, protons and siderophores $[18,19]$. The P-solubilizing activity is determined by the ability of the microbes to release metabolites such as organic acids, which through their hydroxyl and carboxyl groups chelate the cations bound to phosphate, the latter being converted to soluble forms [20]. Kpomblekou and Tabatabai [21] indicated that P-solubilizing capacities of organic acids are highly correlated with the amount of $\mathrm{OH}$ and $\mathrm{COOH}$ groups and their relative positions on the main carbon chain. The use of organic acids and phenolic compounds that are present in OMW represents a new perspective in RP research and a possible solution for the recycling of the OMW. This report suggests that agronomic application of OMW with RP enhances the fertilizer value of RP especially in alkaline soils where solubilization of RP as such is not possible.

Little is known about the efficiency of the direct application of Gafsa (Tunisia, West sector) RP on tree growth. A possible long-term solubilization of RP could favour their utilization as low external inputs for olive trees culture in semi-arid zones. However, the alkaline soils are often encountered to the use of RP as fertilizers. This could be detrimental to the solubilization of RP [22]. The objectives of this paper were: 1) To provide information on the ability of OMW to release $\mathrm{P}$ from RP after 5 years of agronomic application of OMW and RP. 2) To study the impact of the potential use of OMW with RP as soil amendment on physiological and biochemical changes in olive trees. Specific attention was paid to the development of colonisation in the olive tree roots.

\section{Materials and Methods}

\section{Field site and sampling}

Experimental design used in this work was described previously [23]. Briefly, the study area consisted of a field, with trees spaced 12 $\times 12 \mathrm{~m}$ apart, located in Sidi Bou Ali (Sahel of Tunisia). The climate is temperate and semi-arid. The mean annual temperature ranges between 17 and $19^{\circ} \mathrm{C}$ and the mean annual rainfall between 250 and $350 \mathrm{~mm}$. Physico-chemical characteristics of the olive trees soil used in this study were as follows - $\mathrm{pH}\left(\mathrm{H}_{2} \mathrm{O}\right): 8.71$; sand: $81 \%$; clay: $12 \%$; silt: 7\%; organic C: $0.26 \%$; N: 0.032\%; olsen P: $21.57 \mathrm{mg} \mathrm{kg}^{-1}$; exchangeable $\mathrm{K}: 5.04 \mathrm{mg} \mathrm{kg}^{-1}$.

The experimental design was completely randomised with three treatments and three replications $\left(\mathrm{n}=3\right.$; field plots of $\left.1152 \mathrm{~m}^{2}\right)$. The treatments were: (1) M0: $0 \mathrm{~m}^{3} \mathrm{ha}^{-1}$ of $\mathrm{OMW}+0 \mathrm{~kg} \mathrm{ha}^{-1}$ of RP; (2) M1PN: $30 \mathrm{~m}^{3} \mathrm{ha}^{-1}$ of OMW+150 kg ha-1 of RP; (3) M2PN: $60 \mathrm{~m}^{3} \mathrm{ha}^{-1}$ of OMW+150 kg ha-1 of RP. This amendment was realised during two successive years. All sampling events included the collection of a composite soil sample $(0-20 \mathrm{~cm}$ deep) from each plot at approximately after 5 years of agronomic application of OMW and RP. In the laboratory, soil subsamples were sieved $(<2 \mathrm{~mm})$ and used for soil nitrogen, phosphorus, potassium and fatty acids measurements. Roots and leaves were collected at this time. A composite root sample was collected from each plot at $10-20 \mathrm{~cm}$ depth. The roots were washed and were then divided into two fractions, one for fatty acid analysis and the other used for soluble carbohydrate measurements. From each plot, approximately 100 mature leaves were collected in paper bags and stored in a portable ice chest. Once in the laboratory, leaves were washed with $0.03 \%$ Triton X-100 and rinsed in deionized water.

\section{Soil nitrogen, phosphorus and potassium}

Total nitrogen $\left(\mathrm{N}_{\text {tot }}\right)$ was determined by Kjeldahl digestion [24]. Available phosphorus $\left(\mathrm{P}_{\text {avail }}\right)$ analysis was measured by the method of Olsen and Sommers [25]. Exchangeable $\mathrm{K}\left(\mathrm{K}_{\text {exch }}\right)$ was extracted with $\mathrm{NH}_{4} \mathrm{OAC}$ at $\mathrm{pH} 7$ and measured by emission spectroscopy.

\section{Total microbial biomass, AM fungal biomass and development of colonisation in the olive tree roots}

Soil FAME 16:1 $\omega 5$ and roots FAME 16:1 $\omega 5$ were determined using the ester-linked fatty acid methyl ester (EL-FAME) method as described previously [26]. Briefly, soil (3 g) and root (30 mg) samples were treated by methanolic $\mathrm{KOH}$ and acetic acid, and then fatty acids were extracted by hexane, the suspensions were vortexed and centrifuged to separate the phases. The hexane layer was transferred to a clean tube, and the hexane was evaporated off, after which FAMEs were resuspended in $0.5 \mathrm{ml}$ of hexane-methyl tert-butyl ether (1:1) and transferred to a Hewlett-Packard 5890 gas chromatograph equipped with a flame ionisation detector and a HP-5MS capillary column (95\% dimethyl-5\% diphenyl polysiloxane, length $30 \times 0.25 \mathrm{~mm}$ ). The temperature was programmed to increase from 170 to $270^{\circ} \mathrm{C}$ at a rate of $5^{\circ} \mathrm{C}$ per min. The temperature was increased to $270^{\circ} \mathrm{C}$ for $2 \mathrm{~min}$ between samples in order to clean the column. Individual peaks were identified based on the relative retention time of known fatty acids in the standard mixture.

The total amount of extractable FAME was used as indicators of total microbial biomass [27]. Soil FAME 16:1 $\omega 5$ was used to indicate AM fungal biomass [26-28]. Root FAME 16:1 $\omega 5$ analysis was used as index for the development of AM fungus colonisation in the olive tree roots [26-29].

\section{Roots soluble carbohydrate determination}

The soluble carbohydrates from composite root samples were extracted twice in $80 \%$ ethanol at $70^{\circ} \mathrm{C}$ [26]. Extracts were dried and converted into trimethylsilyl ethers with a silylation mixture made up of pyridine, hexamethyldisilazane and trimethylchlorosilane. An aliquot of $1 \mu \mathrm{l}$ of each silylated total extract of the root samples was analyzed using a Hewlett-Packard 5890 series II gas chromatograph equipped with a flame ionisation detection (FID) system and a HP-5MS capillary column $(30 \mathrm{~m} \times 0.25 \mathrm{~mm})$. Injector and detector temperatures were $280^{\circ} \mathrm{C}$ and $300^{\circ} \mathrm{C}$, respectively. The following temperature program was set: $80^{\circ} \mathrm{C}$ for $1 \mathrm{~min}$, followed from 80 to $170^{\circ} \mathrm{C}$ at $10^{\circ} \mathrm{C} / \mathrm{min}$, from 170 to $200^{\circ} \mathrm{C}$ at $15^{\circ} \mathrm{C} / \mathrm{min}$, from 200 to $315^{\circ} \mathrm{C}$ at $25^{\circ} \mathrm{C} / \mathrm{min}$ and finally $315^{\circ} \mathrm{C}$ for 8 minutes. Data were acquired and processed with the HP (Agilent) Chemstation software. Using this program, $23.6 \mathrm{~min}$ were required to elute the trimethylsilyl derivatives. All reference compounds were analyzed in the same way. Identification of individual carbohydrate was achieved by comparing their retention times with those of reference compounds. The concentration was expressed in $\mu \mathrm{g}$ of carbohydrate per $\mathrm{mg}$ of roots $\left(\mu \mathrm{g} \mathrm{m}^{-1}\right)$.

\section{Determination of pigment content}

A leaf sample $(0.5 \mathrm{~g})$ was mashed in a mortar and pestle with $80 \%$ acetone $(\mathrm{v} / \mathrm{v})$, the extract was filtered and centrifuged at $15000 \mathrm{~g}$ for $5 \mathrm{~min}$. The supernatant was collected and read at 663 and $647 \mathrm{~nm}$ for total chlorophyll, chlorophyll a and chlorophyll b [30]. Data were expressed as milligrams per gram fresh weight (FW).

\section{Total polyphenol content}

The total polyphenols were extracted according to the method 
Citation: Mechri B, Tekaya M, Cheheb H, Hammami M, Attia F (2015) Agronomic Application of Olive Mill Wastewater with Rock Phosphate Influence Soil Phosphorus Availability, Arbuscular Mycorrhizal Fungal Colonisation and Olive Tree Performance under Long-Term Field Conditions. J Environ Anal Toxicol 5: 300. doi:10.4172/2161-0525.1000300

Page 3 of 7

described by Kiritsakis et al. [31] and determined spectrophotometrically at $765 \mathrm{~nm}$, using the Folin-Ciocalteu reagent. The concentration of total phenol compounds for each extract was calculated on the basis of a standard curve obtained using gallic acid as a standard. Results were expressed as $\mu \mathrm{g}$ of gallic acid per $\mathrm{g}$ of fresh weight (FW).

\section{Statistical analysis}

The data obtained were statistically analysed using the SPSS statistical software Version 10.0 (SPSS Inc., Chicago, IL, USA). The significance of differences between mean values was determined by one-way analysis of variance. Duncan's multiple range test was used to compare the means. The significance probability levels of the results are given at the $\mathrm{P}<0.05$ level. Sample variability is given as the standard error of the mean values. The number of replicates for each measurement is provided in the table descriptions and figure legends.

\section{Results and Discussion}

\section{Olive mill wastewaters and rock phosphates characterization}

OMW samples were acidic ( $\mathrm{pH} 4.7)$ with a medium conductivity $\left(8.3 \mathrm{ds} \mathrm{m}^{-1}\right)$, relatively low amounts of $\mathrm{N}\left(0.7 \mathrm{~g} \mathrm{l}^{-1}\right), \mathrm{P}\left(0.2 \mathrm{~g} \mathrm{l}^{-1}\right)$ and a moderate amount of $\mathrm{K}\left(4.3 \mathrm{~g} \mathrm{l}^{-1}\right)$. Analyses by HPLC showed a predominance of hydroxytyrosol $\left(167.79 \mathrm{mg} \mathrm{kg}^{-1}\right)$, phenyl acetic acid (111.17 mg kg $\left.\mathrm{mg}^{-1}\right)$, tyrosol (58.23 $\left.\mathrm{mg} \mathrm{kg}^{-1}\right), \mathrm{m}$-Coumaric acid $(49.75 \mathrm{mg}$ $\left.\mathrm{kg}^{-1}\right)$, rosmarinic acid $\left(28.07 \mathrm{mg} \mathrm{kg}^{-1}\right)$, iso- vanillic acid $\left(22.72 \mathrm{mg} \mathrm{kg}^{-1}\right)$, 3 -Hydroxybenzoic acid $\left(21.55 \mathrm{mg} \mathrm{kg}^{-1}\right)$ and moderately quantities of catechol (15.52 mg kg$\left.{ }^{-1}\right)$, caffeic acid $\left(15.37 \mathrm{mg} \mathrm{kg}^{-1}\right)$, oleuropein (11.94 $\mathrm{mg} \mathrm{kg}{ }^{-1}$ ), vanillic acid (10.49 $\mathrm{mg} \mathrm{kg}^{-1}$ ), (Protocatechuic acid (10.48 mg $\left.\mathrm{kg}^{-1}\right)$, syringic acid $\left(9.36 \mathrm{mg} \mathrm{kg}^{-1}\right)$ and ferulic acid $\left(8.33 \mathrm{mg} \mathrm{kg}^{-1}\right)$.

The RP used in this experiment come from Gafsa and is composed by $22.19 \% \mathrm{P}_{2} \mathrm{O}_{5}, 48.73 \% \mathrm{CaO}, 1.78 \% \mathrm{SiO}_{2}, 0.54 \% \mathrm{MgO}, \mathrm{F} 3.79 \%, 0.45 \%$ $\mathrm{Al}_{2} \mathrm{O}_{3}, 0.21 \% \mathrm{Fe}_{2} \mathrm{O}_{3}, 1.25 \% \mathrm{Na}_{2} \mathrm{O}, 0.08 \% \mathrm{~K}_{2} \mathrm{O}, 6.62 \% \mathrm{CO}_{2}, 1.33 \% \mathrm{H}_{2} \mathrm{O}$, $1.41 \% \mathrm{~S}, 16$ ppm MnO, 434 ppm Zn, 10 ppm Cu, 5 ppm Co [32].

Olive mill wastewaters and rock phosphates effects on soil microbial biomass and mineral elements profile

Results presented in this study demonstrate that the mineral elements, especially $\mathrm{P}_{\text {avail }}$ and $\mathrm{K}_{\text {exch }}$ of soils amended with different concentrations of OMW and RP were modified significantly (Figure 1). Soil $\mathrm{K}_{\text {exch }}$ was higher in the treated soils in comparison with the control. These increases are directly caused by the high content of K in the OMW and are in agreement with what has been previously observed by several authors [33,34]. These $\mathrm{K}$ increases are beneficial for crop productivity and health according to the different plant requests and uptake efficiency and can have ecological and economical advantages avoiding or reducing the use of $\mathrm{K}$ fertilisers $[35,36]$. It is important to emphasize that adequate $\mathrm{K}$ fertilization allows better tolerance to drought, which is very frequent under our Mediterranean conditions [37].

Plant mineral nutrition depends mainly on the phosphorus content of soil, which can be assimilated only as soluble phosphate. However their solubilization rarely occurs in non acidic soils [17]. Several studies have shown that microorganisms can increase $\mathrm{P}$ availability through solubilisation of poorly available phosphates by lowering the $\mathrm{pH}$ or excreting organic acid anions [18,19-38]. In the present study, the smaller concentration of available $\mathrm{P}$ in the OMW and RP amended soil, compared to the control soil, suggests that amended soil contains less microbial biomass. However, the application of the OMW with PR to the soil was associated with an increase in the microbial biomass, as measured by total amount of extractable FAMEs (Figure 2). Increased microbial counts and biomass following OMW application were also observed in other studies $[39,40]$. Thus, the lower $\mathrm{P}$ observed in the soil amended with OMW and RP could be caused by the free carbonate contained in Gafsa RP. The results obtained by Kpomblekou-A and Tabatabai [41] confirm that the free carbonate present in RP depresses
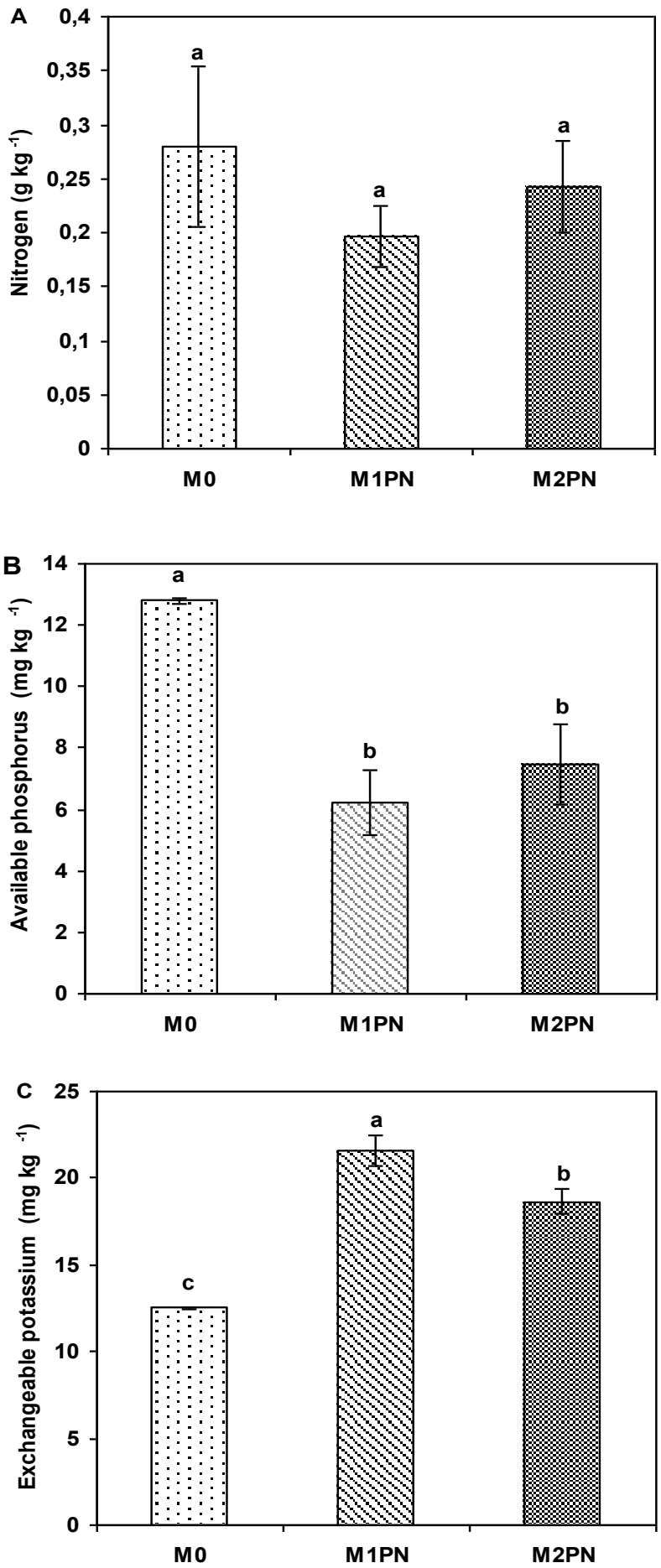

Figure 1: Soil total nitrogen (A), available phosphorus (B) and exchangeable potassium (C) after five years of agronomic application of OMW with RP (average $\pm S E$. $n=3$ ). Different letters indicate significantly different values at $\mathrm{P} \leq 0.05$ according to Duncan test. 
Citation: Mechri B, Tekaya M, Cheheb H, Hammami M, Attia F (2015) Agronomic Application of Olive Mill Wastewater with Rock Phosphate Influence Soil Phosphorus Availability, Arbuscular Mycorrhizal Fungal Colonisation and Olive Tree Performance under Long-Term Field Conditions. J Environ Anal Toxicol 5: 300. doi:10.4172/2161-0525.1000300

Page 4 of 7

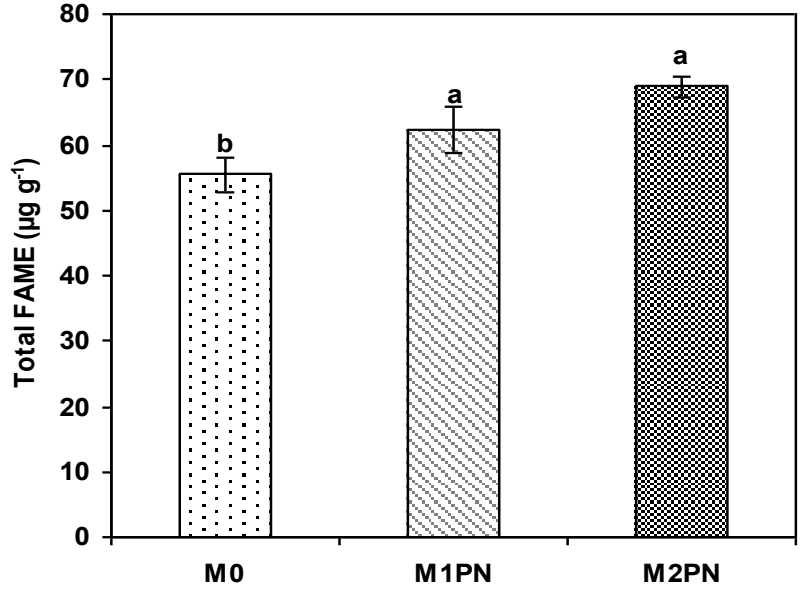

Figure 2: Response of total microbial biomass, as measured by total amount of extractable FAMEs, to the agronomic application of OMW with RP (average $\pm S E . n=3)$. Different letters indicate significantly different values at $P \leq 0.05$ according to Duncan test.

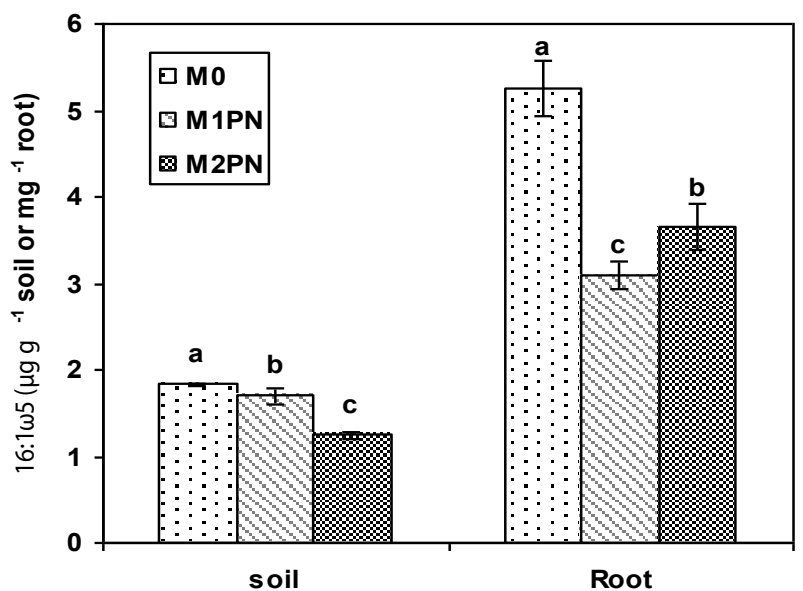

Figure 3: Effect of agronomic application of OMW with RP on the biomass of arbuscular mycorrhizal (AM) fungi, as measured by soil fatty acid methyl ester (FAME) 16:1 $\omega 5$, and on the development of colonisation in the olive trees roots, as measured by roots FAME 16:1 $\omega 5$ (average \pm SE. $n=3$ ). Different letters indicate significantly different values at $P \leq 0.05$ according to Duncan test.

P solubility. Another explication for the decline in the extractable soil $\mathrm{P}$ observed in the OMW and RP amended soil can be related to the accessory minerals contained in Gafsa $\mathrm{RP}$ especially $\mathrm{Ca}, \mathrm{Mg}, \mathrm{Al}_{2} \mathrm{O}_{3}$ and $\mathrm{Fe}_{2} \mathrm{O}_{3}$, that can interfere with $\mathrm{P}$ release from OMW or soil organic- $\mathrm{P}$, thereby reducing extractable soil P. According to Kpomblekou-A and Tabatabai [41] the presence of $\mathrm{Ca}$ and $\mathrm{Mg}$ ions (as impurities) in the RP must be responsible for the increase in $\mathrm{pH}$ of the equilibrium solution and must have contributed to the decrease in the P solubility.

A third factor related to the decrease of soil $\mathrm{P}$ after agronomic application of OMW with RP could be related to the lower soil FAME 16:1 $\omega 5$ and root FAME 16:1 $\omega 5$ (Figure 3). Soil FAME 16:1 $\omega 5$ was used to indicate AM fungal biomass [27-29] and Root FAME 16:1 $\omega 5$ analysis was used as index for the development of AM fungus colonisation in the olive tree roots [27-30]. Ipsilantis et al. [42] showed that extraradical hyphae of AM fungi can hydrolyse organic-P and actively produce phosphatase enzymes involved in $\mathrm{P}$ release from organic compounds in soils. Duponnois et al. [38] indicated that mycorrhizal fungi can solubilize RP through excretion of organic acids such as a-ketoglutaric acid. This organic compound could exert a selective influence on soil microbial communities though a multiplication of $\alpha$-ketoglutarate catabolizing microorganisms. Ouahmane et al. [43] reported that substrate induced respiration (SIR) response with carboxylic acids was higher in the soil inoculated with AM fungi. In the process of phosphate solubilization, among the identified carboxylic acids, dicarboxylic (oxalic, tartaric, malic, fumaric, malonic acids) and tricarboxylic acids (citric acid) were effective in phosphorus mobilization [44]. AM fungi and their associated hyphosphere microflora excreted higher amounts of such organic acids [43].

Olive mill wastewaters and rock phosphates effects on AM fungal biomass and development of colonisation in the olive tree roots

The negative impact of agronomic application of OMW with RP on the AM fungal biomass and the development of colonisation in the olive tree roots may be related to the higher amount of OMW phenolic compounds, which are well known antimicrobial and phytotoxic agents [45]. The major phenolic compounds identified in the OMW used in this study are hydroxytyrosol, chlorogenic, protocatechuic, tyrosol, hydroxyphenyl acetic, 4-Hydroxybenzoic, caffeic, syringic, catechol, vanillic, isovanillic, 3-Hydroxybenzoic, oleuropein, p-Coumaric, $\mathrm{m}$-Coumaric, o-Coumaric, ferulic, rosmarinic, vanillin, phenyl acetic, apigenin and naphtoresorcinol. Martín et al. [46] indicated that the application of $2.5 \mathrm{~g} \mathrm{~kg}^{-1}$ of olive mill dry residue $\left(15 \mathrm{mg} \mathrm{kg}^{-1}\right.$ of phenolic content) was enough to decrease root colonisation and the percentage of root length colonized with indigenous AM fungi. Vassilev et al. [47] have reported that in the case of plants amended with untreated OMW, the highest concentration of polyphenols was the most reason for the lowest value of AM colonization. Fries et al. [48] indicated that soil application of phenolic acids (p-Coumaric acid, hydroxybenzoic acid and quercetin) which are considered as a source of OMW biotoxicity at high rates, might negatively affect AM colonization and growth of sorghum plants.

\section{Olive mill wastewaters and rock phosphates effects on olive tree performance}

Agronomic application of OMW with RP decreased significantly the concentration of root carbohydrates in M1PN and M2PN treatments (Table 1). More specific, in olive trees treated with M2PN,

\begin{tabular}{|l|c|c|c|}
\hline & \multicolumn{3}{|c|}{ Treatments } \\
\hline Sugars $\left(\mu \mathrm{g} \mathrm{mg}^{-1}\right)$ & M0 & M1PN & M2PN \\
\hline Fructose & $2.01 \pm 0.37 \mathrm{a}$ & $1.03 \pm 0.31 \mathrm{~b}$ & $0.78 \pm 0.24 \mathrm{~b}$ \\
\hline Galactose & $0.23 \pm 0.03 \mathrm{a}$ & $0.13 \pm 0.04 \mathrm{~b}$ & $0.11 \pm 0.02 \mathrm{~b}$ \\
\hline Glucose & $5.57 \pm 0.71 \mathrm{a}$ & $1.94 \pm 0.2 \mathrm{~b}$ & $2.11 \pm 0.56 \mathrm{~b}$ \\
\hline Mannitol & $3.39 \pm 0.19 \mathrm{a}$ & $2.46 \pm 0.07 \mathrm{~b}$ & $2.42 \pm 0.56 \mathrm{~b}$ \\
\hline Sorbitol & $0.05 \pm 0.01 \mathrm{a}$ & $0.05 \pm 0.01 \mathrm{a}$ & $0.04 \pm 0.01 \mathrm{a}$ \\
\hline Sucrose & $1.41 \pm 0.12 \mathrm{a}$ & $1.05 \pm 0.03 \mathrm{~b}$ & $0.68 \pm 0.22 \mathrm{c}$ \\
\hline Total & $12.67 \pm 0.52 \mathrm{a}$ & $6.66 \pm 0.58 \mathrm{~b}$ & $6.15 \pm 1.58 \mathrm{~b}$ \\
\hline
\end{tabular}

The effect of OMW treatment was tested with one-way ANOVA (mean value \pm $\mathrm{SE}, \mathrm{n}=3$ ), and mean values in individual lines followed by the same letter are not significantly different at $\mathrm{P}<0.05$ (Duncan test)

Table 1: Effect of agronomic application of OMW with RP on olive tree rootsoluble carbohydrates (M0: $0 \mathrm{~m}^{3} \mathrm{ha}^{-1}$ of OMW+0 $\mathrm{kg} \mathrm{ha}^{-1}$ of RP, M1PN: $30 \mathrm{~m}^{3}$ ha-1 of OMW+150 kg ha-1 of RP and M2PN: $60 \mathrm{~m}^{3} \mathrm{ha}^{-1}$ of OMW+150 kg ha-1 of RP). 
Citation: Mechri B, Tekaya M, Cheheb H, Hammami M, Attia F (2015) Agronomic Application of Olive Mill Wastewater with Rock Phosphate Influence Soil Phosphorus Availability, Arbuscular Mycorrhizal Fungal Colonisation and Olive Tree Performance under Long-Term Field Conditions. J Environ Anal Toxicol 5: 300. doi:10.4172/2161-0525.1000300

sucrose and mannitol decreased by $52 \%$ and $29 \%$ respectively, which indicates that $\mathrm{C}$ allocation to the root system was affected following agronomic application of OMW with RP. The application of OMW with RP caused also a significant decrease in the glucose, fructose and galactose contents, whereas no significant differences were found in the amount of sorbitol (Table 1).

AM fungi colonization results in an enhanced "sink" demand for carbon in roots [49]. This sink effect could account for an extra drain $10-23 \%$ of carbon from the host by the AM fungus [50]. To our knowledge the decreased root colonisation observed after agronomic application of OMW with RP might have decreased the translocation of sucrose and mannitol to roots in OMW and RP amended olive trees, thus reducing the root carbohydrate level. It is known that sucrose and mannitol are the principal photosynthetic products and the major phloem-translocated carbohydrates in Olea europaea [51,52].

The decrease in the concentration of root glucose and fructose in M1PN and M2PN treatments may have been caused by the decline in root sucrose level due to the decreased root colonisation. Probably the decreased sucrose allocation to olive tree roots in M1PN and M2PN treatments was associated with a reduction of the activities of sucrose synthase and invertase, which in turn, could affect the amount of glucose and fructose in olive tree roots amended with OMW and RP. It is known that sucrose is cleaved by sucrose synthase and invertase of plant origin to glucose and fructose [53]. The sucrose-cleaving enzymes of plants are crucial for development, growth and carbon partitioning [53]. The effect of agronomic application of OMW and RP on sucrose synthase and invertase activities should be examined in further studies.

Agronomic application of OMW with RP has significantly affected the amount of total chlorophyll, chlorophylls a and b in the olive tree leaves (Figure 4). These data are consistent with those of Mekki et al. [54], who reported that OMW caused a significant reduction of chlorophylls a and b for tomato, chickpea, beans, wheat and barley. Ouzounidou et al. [55] reported that the significant loss of chlorophyll content in the OMW treated plants (Lycopersicon esculentum), may be attributed to the interference of the toxic substances present in OMW in the formation of chlorophyll. Recently, Asfi et al. [56] indicated that the decrease in chlorophyll content after OMW application could not be due to inhibition of plant growth, but to a combined effect of pigment degradation and biosynthesis impairment.

Many environmental conditions that cause oxidative stress are associated with the induction of phenylpropanoid metabolism in plants [57]. This suggests that phenolics are involved in protection against oxidative stress under adverse environmental conditions. El Hadrami et al. [58] suggested that the phytotoxicity effect of OMW on fertirrigated crops results in an oxidative stress. In our study, a significant increase of total polyphenol was observed in M1PN and M2PN treatments (Figure 5). Changes in olive leaf total phenol content have been observed in various environmental stresses and it was claimed that phenolics acted as antioxidants [59-61].

\section{Conclusions}

In summary, the use of OMW in combination with RP, to mobilise $\mathrm{P}$ from RP to olive trees, are expected to have a major negative impact on the available soil $\mathrm{P}$ and the olive tree performance. This study indicates that agronomic application of OMW with RP may reduce the carbon pathway via mycorrhizal fungi, and that this may lead to the loss of carbon from ecosystems due to less formation of stable mycorrhizal carbon pools.

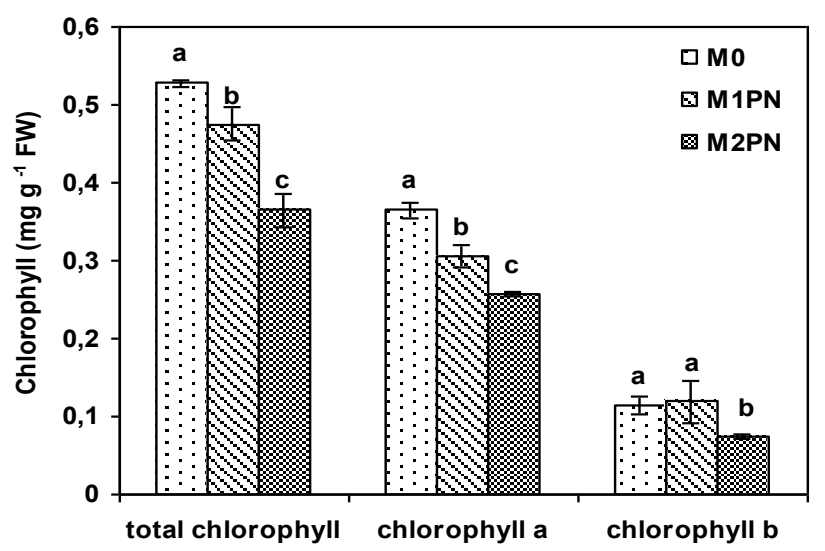

Figure 4: Total chlorophyll, chlorophyll a and chlorophyll b contents of olive tree leaves after five years of agronomic application of OMW with RP (average $\pm S E . n=3$ ). Different letters indicate significantly different values at $P \leq 0.05$ according to Duncan test.

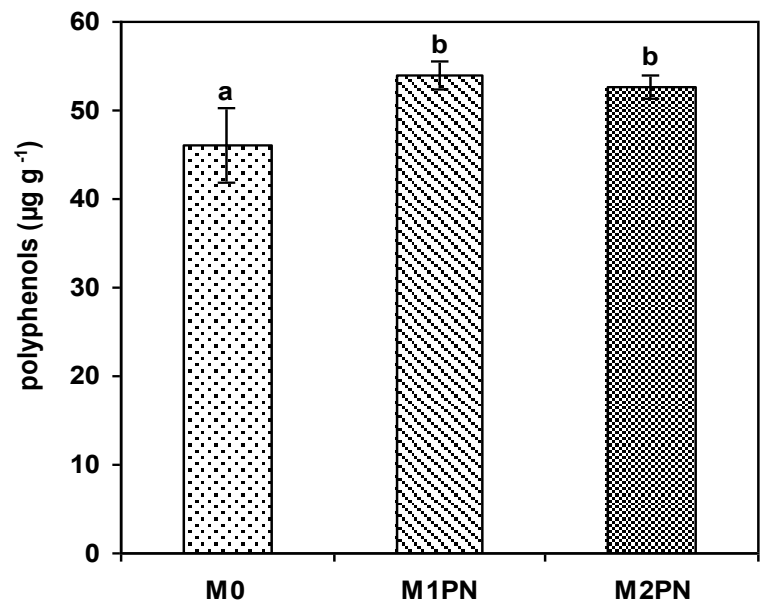

Figure 5: Total polyphenol content of olive tree leaves after five years of agronomic application of OMW with RP (average \pm SE. $n=3$ ). Different letters indicate significantly different values at $\mathrm{P} \leq 0.05$ according to Duncan test.

\section{Acknowledgement}

Thanks to financial support provided by Tunisian Ministry of Enseignement Superieur, Scientific Research and Technology (UR03/ES-08) and to the contribution of Institut de l'Olivier de Sousse-Tunisie.

\section{References}

1. Hannachi H, Msallem M, Ben Elhadj S, El Gazzah M (2007) Influence du site géographique sur les potentialités agronomiques et technologiques de l'olivier (Olea europaea L.) en Tunisie. C R Biol 330: 135-142.

2. Bubonja-Sonje M, Giacometti J, Abram M (2011) Antioxidant and antilisterial activity of olive oil, cocoa and rosemary extract polyphénols. Food Chem 127 1821-1827.

3. Nakbi A, Tayeb W, Dabbou S, Chargui I, Issaoui M, et al. (2012) Hypolipidimic and antioxidant activities of virgin olive oil and its fractions in 2,4-diclorophenoxyacetic acid-treated rats. Nutrition 28: 81-91.

4. Angelakis AN, Marecos Do Monte MHF, Bontoux L, Asano T (1999) The status of wastewater reuse practice in the Mediterranean basin: need for guidelines. Water Res 10: 2201-2217.

5. Hochstrat R, Wintgens T, Melin T, Jeffrey P (2006) Assessing the European 
Citation: Mechri B, Tekaya M, Cheheb H, Hammami M, Attia F (2015) Agronomic Application of Olive Mill Wastewater with Rock Phosphate Influence Soil Phosphorus Availability, Arbuscular Mycorrhizal Fungal Colonisation and Olive Tree Performance under Long-Term Field Conditions. $J$ Environ Anal Toxicol 5: 300. doi:10.4172/2161-0525.1000300

wastewater reclamation and reuse potential - a scenario analysis. Desalination 188:1-8

6. Marecos Do Monte MHF, Angelakis AN, Asano T (1996) Necessity and basis for establishment of European guidelines for reclaimed wastewater in the Mediterranean region. Water Sci Technol 33: 303-316.

7. Khabou W, Ben Amar F, Rekik H, Beghi M, Touir A (2009) Performance evaluation in olive trees irrigated by treated wastewater. Desalination 246: 329-336.

8. Reddy MS, Kumar S, Khosla B (2002) Biosolubilization of poorly soluble rock phosphates by Aspergillus tubingensis and Aspergillus niger. Bioresource Technol 84: 187-189.

9. Simpson PG, Sale PWG, Tennakoon SB (1997) An economic analysis of the field performance of North Carolina reactive phosphate rock compared with single superphosphate for selected sites from the National Reactive Phosphate Rock Project. Aus J Exp Agr 37: 1061-1076.

10. Roig A, Cayuela ML, Sánchez-Monedero MA (2006) An overview on olive mil wastes and their valorisation methods. Waste Management 26: 960-969.

11. Mechri B, Manga AGB, Tekaya M, Attia F, Cheheb H, et al. (2014) Changes in microbial communities and carbohydrate profiles induced by the mycorrhizal fungus (Glomus intraradices) in rhizosphere of olive trees (Olea europaea L.). Appl Soil Ecol 75: 124-133.

12. Porras-Soriano A, Sorano-Marintin ML, Porras-Piedra A, Azcon P (2009) Arbuscular mycorrhizal fungi increased growth, nutrient uptake and tolerance to salinity in olive trees under nursery conditions. J Plant Physiol 166: 1350-1359.

13. McGee $P$ (1989) Variation in propagule numbers of vesicular-arbuscular mycorrhizal fungi in a semi-arid soil. New Phytopathol 92: 28-33.

14. Bolan NS (1991) A critical review on the role of mycorrhizal fungi in the uptake of phosphorus by plant. Plant Soil 134: 189-207.

15. Taylor J, Harrier LA (2001) A comparison of development and mineral nutrition of micropropagated Fragaria $\times$ ananassa cv. Elvira (strawberry) when colonised by nine species of arbuscular mycorrhizal fungi. Appl Soil Ecol 18: 205-215.

16. Smith SE, Read DJ (2008) Mycorrhizal symbiosis. London: Academic Press.

17. Caravaca F, Alguacil MM, Azcon R, Diaz G, Roldan A (2004) Comparing the effectiveness of mycorrhizal inoculum and amendment with sugar beet, rock phosphate and Aspergillus niger to enhance field performance of the leguminous shrub Dorycnium pentaphyllum L. Appl Soil Ecol 25: 169-180.

18. Relwani L, Krishna P, Reddy MS (2008) Effect of carbon and nitrogen sources on phosphate solubilization by a wild-type strain and UV-induced mutants of Aspergillus tubingensis. Curr Microbiol 57: 401-406.

19. Singh H, Reddy MS (2011) Effect of inoculation with phosphate solubilizing fungus on growth and nutrient uptake of wheat and maize plants fertilized with rock phosphate in alkaline soils. Eur J Soil Biol 47: 30-34

20. Sagoe Cl, Ando T, Kouno K, Nagaoka T (1998) Relative importance of protons and solution calcium concentration in phosphate rock dissolution by organic acids. Soil Sci Plant Nutr 44: 617-625.

21. Kpomblekou-A AK, Tabatabai MA (1994) Effect of organic acids on release of phosphorus from phosphate rocks. Soil Sci 158: 442-453.

22. Robinson JS, Syers JK (1990) A critical evaluation of the factors influencing the dissolution of Gafsa phosphate rock. J Soil Sci 41: 597-605.

23. Mechri B, Echbili A, Issaoui M, Braham M, Elhadj SB, et al. (2007) Short-term effects in soil microbial community following agronomic application of olive mill wastewaters in a field of olive trees. Appl Soil Ecol 36: 216-223.

24. Keeney DR, Nelson DW (1982) Nitrogen-inorganic forms. In: Page, Mille AL, Keeney RH (eds.) Methods of Soil Analysis, Part 2. American Society of Agronomy, Madison, WI 643-698.

25. Olsen R, Sommers LE (1982) Phosphorous. In: Page, Miller AL, Keeny $\mathrm{RH}$ (eds.) Methods of Soil Analysis, Part 2. American Society of Agronomy, Madison, 403-430

26. Mechri B, Ben Mairem B, Baham M, Elhadj SB, Hammami M (2008) Change in soil properties and the soil microbial community following land spreading of olive mill wastewater affects olive trees key physiological parameters and the abundance of arbuscular mycorrhizal fungi. Soil Biol Biochem 40: 152-161.

27. Zelles L (1997) Phospholipid fatty acid profiles in selected members of soil microbial communities. Chemosphere 35: 275-294.
28. Olsson PA, Bååth E, Jakobsen I, Soderstrom B (1995) The use of phospholipid and neutral lipid fatty-acids to estimate biomass of arbuscular mycorrhizal fung in soil. Mycol Res 99: 623-629.

29. Olsson PA, Baath E, Jakobsen I (1997) Phosphorus effects on mycelium and storage structures of an arbuscular mycorrhizal fungus as studied in the soil and roots by fatty acid signatures. Appl Environ Microbiol 63: 3531-3538.

30. El Hadrami A, Belaqziz M, El Hassni M, Hanifi S, Abbad A, et al. (2004) Physicochemical characterization and effects of olive oil mill wastewaters fertirrigation on the growth of some Mediterranean crops. J Agron 3: 247-254.

31. Kiritsakis K, Kontominas MG, Kontogiorgis C, Hadjipavlou-Litina D, Moustakas A, et al. (2010) Composition and antioxidant activity of olive leaf extracts from greek olive cultivars. J Am Oil Chem Soc 87: 369-376.

32. IFDC (1995) Evaluation of Gafsa (Tunisia) phosphate rock for direct application Final Report presented by International Fertilizing Development Center in September, 80.

33. Kavvadias V, Doula MK, Komnitsas K, Liakopoulou N (2010) Disposal of olive oil mill wastes in evaporation ponds: effects on soil properties. J Hazard Mater 182: 144-155.

34. Di Bene C, Pellegrino E, Debolini M, Silvestri N, Bonari E (2013) Short and long-term effects of olive mill wastewater land spreading on soil chemical and biological properties. Soil Biol Biochem 56: 21-30.

35. Arienzo M, Christen EW, Quayle W, Kumar A (2009) A review of the fate of potassium in the soil-plant system after land application of wastewaters. J Hazard Mater 164: 415-422.

36. Chartzoulakis K, Psarras G, Moutsopoulou M, Stefanoudaki E (2010) Application of olive mill wastewater to a Cretan olive orchard: effects on soil properties, plant performance and the environment. Agric Ecosyst Environ 138 293-298.

37. López-Granados F, Jurado-Expósito M, Álamo S, García-Torres L (2004) Leaf nutrient spatial variability and site-specific fertilization maps within olive (Olea europaea L.) orchards. Eur J Agron 21: 209-222.

38. Duponnois R, Colombet A, Hien V, Thioulouse J (2005) The mycorrhizal fungus Glomus intraradices and rock phosphate amendment influence plan growth and microbial activity in the rhizosphere of Acacia holosericea. Soil Bio Biochem 37: 1460-1468.

39. Saadi I, Laor Y, Raviv M, Medina S (2007) Land spreading of olive mill wastewater: Effects on soil microbial activity and potential phytotoxicity. Chemosphere 66: 75-83.

40. El Hassani FZ, Zinedine A, Mdaghri Alaoui S, Merzouki M, Benlemlih M (2010) Use of olive mill wastewater as an organic amendment for Mentha spicata $\mathrm{L}$. Ind Crop Prod 32: 343-348.

41. Kpomblekou-AAK, Tabatabai MA (2003) Effect of low-molecular weight organic acids on phosphorus release and phytoavailabilty of phosphorus in phosphate rocks added to soils. Agric Ecosyst Enviro 100: 275-284.

42. Ipsilantis I, Karpouzas DG, Papadopoulou KK, Ehaliotis C (2009) Effects of soil application of olive mill wastewaters on the structure and function of the community of arbuscular mycorrhizal fungi. Soil Biol Biochem 41: 2466-2476.

43. Ouahmane L, Thioulouse J, Hafidi M, Prin Y, Ducousso M, et al. (2007) Soil functional diversity and $\mathrm{P}$ solubilization from rock phosphate after inoculation with native or allochtonous arbuscular mycorrhizal fungi. Forest Ecol Manag 241: $200-208$.

44. Ryan PR, Delhaise E, Jones DL (2001) Function and mechanism of organic anion exudation from plant roots. Annu Rev Plant phys 52: 527-560.

45. Isidori M, Lavogna M, Nardelli A, Parella A (2005) Model study on the effect of 15 phenolic olive mill wastewater constituents on seed germination and Vibrio fischeri metabolism. J Agr Food Chem 53: 8414-8417.

46. Martín J, Sampedro I, García-Romera JM, García-Garrido JA, Ocampo JA (2002) Arbuscular mycorrhizal colonization and growth of soybean (Glycine max) and lettuce (Lactuca sativa) and phytotoxic effects of olive mill residues. Soil Biol Biochem 34: 1769-1775.

47. Vassilev N, Medina A, Azcón R, Vassileva M (2006) Microbial solubilization of rock phosphate on media containing agro-industrial wastes and effect of the resulting products on plant growth and $\mathrm{P}$ uptake. Plant Soil 287: 77-84. 
Citation: Mechri B, Tekaya M, Cheheb H, Hammami M, Attia F (2015) Agronomic Application of Olive Mill Wastewater with Rock Phosphate Influence Soil Phosphorus Availability, Arbuscular Mycorrhizal Fungal Colonisation and Olive Tree Performance under Long-Term Field Conditions. $J$ Environ Anal Toxicol 5: 300. doi:10.4172/2161-0525.1000300

48. Fries LLM, Pacovsky RS, Safir GR, Siqueira JO (1997) Plant growth and arbuscular mycorrhizal fungal colonization affected by exogenously applied phenolic compounds. J Chem Ecol 23: 1755-1767.

49. Wright DP, Scholes JD, Read DJ (1998) Effects of VA mycorrhizal colonization on photosynthesis and biomass production of Trifolium repens $\mathrm{L}$. Plant Cell Environ 21: 209-216.

50. Jakobsen I, Rosendahl L (1990) Carbon flow into soil and external hyphae from roots of mycorrhizal cucumber plants. New Phytol 115: 77-83.

51. Conde C, Silva P, Alice Agasse A, Lemoine R, Delrot S, et al. (2007) Utilization and transport of mannitol in Olea europaea and implications for salt stress tolerance. Plant Cell Physiol 48: 42-53.

52. Rejšková A, Patková L, Stodůlková E, Lipavska H (2007) The effect of abiotic stresses on carbohydrate status of olive shoots (Olea europaea L.) under in vitro conditions. J Plant Physiol 164: 174-184.

53. Sturm A, Tang GQ (1999) The sucrose-cleaving enzymes of plants are crucial for development, growth and carbon partitioning. Trends Plant Sci 4: 401-407.

54. Mekki A, Dhouib A, Aloui F, Sayadi S (2006) Olive wastewater as an ecological fertilizer. Agron. Sust. Develop 26: 61-67.

55. Ouzounidou G, Asfi M, Sortirakis N, Papadopoulou P, Gaitis F (2008) Olive mil waste water triggered changes in physiology and nutritional quality of tomato (Lycopersicon esculentum Mill.) depending on growth substrate. J Hazard Mater 158: 523-530.

56. Asfi M, Ouzounidou G, Panajiotidis S, Therios I, Moustakas M (2012) Toxicity effects of olive-mill wastewater on growth, photosynthesis and pollen morphology of spinach plants. Ecotox Environ Safe 80: 69-75

57. Mittler R (2002) Oxidative stress, antioxidants, and stress tolerance. Trends Plant Sci 7: 405-410.

58. El Hadrami A, Belaqziz M, El Hassni M, Hanifi S, Abbad A, et al. (2004) Physicochemical characterization and effects of olive oil mill wastewaters fertirrigation on the growth of some Mediterranean crops. J Agron 3: 247-254.

59. Melgar JC, Guidi L, Remorini D, Agati G, Degl'innocenti E, et al. (2009) Antioxidant defenses and oxidative damage in salt-treated olive plants under contrasting sunlight irradiance. Tree Physiol 29: 1187-1198.

60. Remorini D, Melgar JC, Guidi L, Degl'Innocenti E, Castelli S, et al. (2009) Interaction effects of root-zone salinity and solar irradiance on the physiology and biochemistry of Olea europaea. Environ Exp Bot 65: 210-219.

61. Petridis A, Therios I, Samouris G, Tananaki C (2012) Salinity-induced change in phenolic compounds in leaves and roots of four olive cultivars (Olea europaea L.) and their relationship to antioxidant activity. Environ Exp Bot 79: 37-43
Citation: Mechri B, Tekaya M, Cheheb H, Hammami M, Attia F (2015) Agronomic Application of Olive Mill Wastewater with Rock Phosphate Influence Soil Phosphorus Availability, Arbuscular Mycorrhizal Fungal Colonisation and Olive Tree Performance under Long-Term Field Conditions. J Environ Anal Toxicol 5: 300. doi:10.4172/2161-0525.1000300
Submit your next manuscript and get advantages of OMICS Group submissions

Unique features:

User friendly/feasible website-translation of your paper to 50 world's leading languages

Audio Version of published paper

Digital articles to share and explore

Special features:

400 Open Access Journals

30,000 editorial team

21 days rapid review process

Quality and quick editorial, review and publication processing

- Indexing at PubMed (partial), Scopus, EBSCO, Index Copernicus and Google Scholar etc

Sharing Option: Social Networking Enabled

Authors, Reviewers and Editors rewarded with online Scientific Credits

Befter discount for your subsequent articles

Submit your manuscript at: www.omicsonline.org/submission/ 